\title{
LINDANE AND PROPOXUR RESIDUES IN COCOA FROM CENTRAL REGION OF GHANA
}

\author{
J. Apau ${ }^{(1)}$, D.K. Dodoo ${ }^{(2)}$ \\ ${ }^{(1)}$ Department of Chemistry, Kwame Nkrumah University of Science and Technology, Kumasi, \\ Ghana \\ E-mail: apaujoseph@yahoo.com \\ ${ }^{(2)}$ Department of Chemistry, University of Cape Coast, Cape Coast, Ghana
}

\begin{abstract}
Lindane and propoxur residue levels in cocoa samples taken from the Central Region of Ghana were determined. Propoxur and Lindane residues in cocoa were extracted by continuous soxhlet extraction with a 1:1 v/v acetone-chloroform and acetone-hexane (20:80 v/v) mixture for propoxur and lindane respectively for $12 \mathrm{~h}$. The extracts were passed through preconditioned octadecyl (C-18) columns to clean up. The pesticides were then analyzed by gas-liquid chromatography using Flame Ionization Detector (FID) and Electron Capture Detector (ECD) for propoxur and lindane respectively. The concentration range for lindane in cocoa was $0.055-3.318 \mathrm{mg} / \mathrm{kg}$. The concentration range for propoxur was $0.001-0.991 \mathrm{mg} / \mathrm{kg}$. The mean of lindane in cocoa beans were: $0.411 \mathrm{mg} / \mathrm{kg}$, pod $1.113 \mathrm{mg} / \mathrm{kg}$, testa $0.609 \mathrm{mg} / \mathrm{kg}$, placenta $0.905 \mathrm{mg} / \mathrm{kg}$, leaves $0.892 \mathrm{mg} / \mathrm{kg}$ and bark $1.332 \mathrm{mg} / \mathrm{kg}$. The mean concentrations of propoxur in cocoa were: beans $0.235 \mathrm{mg} / \mathrm{kg}$, pod $0.235 \mathrm{mg} / \mathrm{kg}$, placenta $0.276 \mathrm{mg} / \mathrm{kg}$, leaves $0.104 \mathrm{mg} / \mathrm{kg}$, bark $0.491 \mathrm{mg} / \mathrm{kg}$. From the studies it may be preferable to use propoxur for control of pests in cocoa.
\end{abstract}

Keywords: Cocoa, Gas chromatography, Lindane, Pesticides, Propoxur.

\section{INTRODUCTION}

Pesticides have been used extensively over the years and this has resulted in environmental contamination. Organochlorine pesticides (OCs) such as DDT, lindane, alddrin, dieldrin, and heptachlor have been found to be persistent in the environment in general. Lindane belongs to the class IIB (moderately acutely toxic) group of insecticides (UNEP/ILO/WHO, 1994). Most of the adverse human health effects by lindane reported for have been related to agricultural uses (U.S. FDA, 2003). Exposure to large amounts of lindane can harm the nervous system, producing a range of symptoms from headache and dizziness to seizures, convulsions and more rarely death (U.S. FDA, 2003; Alvarez-Pedrerol, 2008). Prenatal exposure to $\beta$ Hexachlorocyclohexane, an isomer of lindane and a production by-product, has been associated with altered thyroid hormone levels and could negatively affect brain development (U.S. EPA, 2001). Lindane, being persistent, is transported long distances by natural processes like global distillation, and it can accumulate and concentrate in food chains (AlvarezPedrerol, 2008). When lindane is used in agri- 


\section{Apau and Dodoo}

culture, an estimated $12-30 \%$ of it volatilizes into the atmosphere, where it is subjected to long-range transport and can be deposited by rainfall. In plants that are transpiring, substantial amount of even very sparingly soluble substances may enter the roots over a period of time and move up to accumulate in the edible part of food crops. Lindane is probably taken up more readily than most of the other members of the group, especially during high rates of application. Tainting or off - flavours of cocoa and root crops has often followed the use of lindane (Environment News Service, 2001). With reported cases of resistance of cocoa pest to lindane coupled with accumulated evidence that the use of lindane led to the destruction of other insects in the ecosystem (Commission for Environmental Cooperation, 2006), lindane is alternated with propoxur.

Propoxur is a non-systemic insecticide which was introduced by Bayer Limited in 1959. It is compatible with most insecticides and fungicides except alkalines, and may be found in combination with azinphosmethyl, chlorpyrifos, cyfluthrin, dichlorvos, disulfoton, or methiocarb. Agricultural applications include cocoa, fruit, maize, rice, vegetables, cotton, forestry, and ornamentals production. Like other carbamates, propoxur can inhibit the action of cholinesterase and disrupt nervous system function. Because it is highly soluble in water, propoxur is moderately persistent, and does not adsorb strongly to soil particles; propoxur has a high potential for groundwater penetration (Howard, 1991; U.S. EPA 1988).

The impact of the excessive use of pesticides, especially organochlorines in the African ecosystem brought scientists together for the first Joint FAO/IAEA meeting on the impact of organochlorine use on the flora and fauna in Africa - Tanzania in 1991 (WHO, 1991). The meeting recommended the need for scientific data on the use, dissipation and bioconcentration of these pesticides. It is in line with this that this project on lindane and propoxur residues in cocoa from the Central Region of
Ghana was chosen. Central Region is a major producer of cocoa and the University of Cape Coast where the project was done is located there. The data obtained could help in policy formulation on the use of lindane and propoxur on cocoa in Ghana.

\section{MATERIALS AND METHODS}

All solvents were purchased from British Drug House (BDH) and were of pesticide residue determination grade. Lindane and propoxur standards were purchased from Ehrenstorfer, $\mathrm{GmbH}$, Germany, in sealed vials. Solid phase extraction (SPE) bond elute C-18, $3 \mathrm{cc} / 500 \mathrm{mg}$ was purchased from Varian Inc., USA. Glassware was washed with detergent, rinsed with distilled water and acetone and were heated to $180{ }^{\circ} \mathrm{C}$ for $2 \mathrm{~h}$ to dry.

Part of the cocoa plant comprising the fruit, leaves and bark was collected from six cocoa growing towns in the Central Region of Ghana. The sampled locations included Abura Dunkwa, Assin Fosu, Breman Asikuma, Twifu Mampong, Jukwa and Berase. In each town five farms which were sprayed by Agriculture Extension officers every year were selected. About 50 samples of fruit, leaves and bark were randomly taken from each farm. Sampling was done from October to December 2006. Ten samples each were taken every two weeks. Samples were collected and washed in distilled water and transferred into labeled storage bags. Prior to analysis samples were stored in freezers and maintained at $4{ }^{\circ} \mathrm{C}$ to prevent deterioration. Samples were air dried for four weeks and pulverized with wiring blender. Lindane residues in cocoa samples were extracted using soxhlet extraction (Therdteppitak et al., 2003). Fifty grams sample was put in extraction thimble, and placed in a soxhlet extractor. The sample was extracted with $150 \mathrm{ml}$ of acetone: hexane $(20: 80 \mathrm{v} / \mathrm{v})$ at $50{ }^{\circ} \mathrm{C}$ for $12 \mathrm{~h}$. The extracts were filtered, concentrated to $1 \mathrm{ml}$ using büchi vacuum rotary evaporator. Each of the raw extracts was then dissolved in $10 \mathrm{ml}$ hexane and passed through pre-conditioned octadecyl (C18) columns at a rate of $2 \mathrm{ml} \mathrm{min}$. The column 
Lindane and Propoxur residues in cocoa...

was washed with $1 \mathrm{ml}, 30 \%$ methanol followed by $1 \mathrm{ml}$ deionized water and was allowed to dry. The sample which was trapped in the column was eluted 5 times with $1 \mathrm{ml}$ aliquots of hexane to recover the lindane residue. Hexane in the sample was allowed to evaporate off, leaving the residue alone in the vial. Concentrated sample was dissolved in $1 \mathrm{ml}$ portion of hexane, mixed thoroughly with a whirl mixer and then transferred to auto sample vial for analysis using Gas chromatograph.

Propoxur residues in cocoa samples were extracted using soxhlet extraction (Bentum et al., 2006). A $50 \mathrm{~g}$ sample was put in extraction thimble, and placed in a soxhlet extractor. The sample was extracted with $150 \mathrm{ml}$ of acetone: chloroform blend $(1: 1 \mathrm{v} / \mathrm{v})$ at $50{ }^{\circ} \mathrm{C}$ for $12 \mathrm{~h}, 10$ $\mathrm{ml}$ buffer solution of EJ-275, $\mathrm{pH}$ buffer at 4 was added to the extracts and partitioned with $20 \mathrm{ml}$ chloroform using a separating funnel. The aqueous layer was discarded. The organic layer was evaporated to $1 \mathrm{ml}$ using vacuum rotary evaporator. The extracts were dissolved in $20 \mathrm{ml}$ hexane and placed in separating funnel and partitioned with $10 \mathrm{ml}$ acetonitrile. The hexane layer was discarded. The acetonitrile layer was evaporated to $1 \mathrm{ml}$ using vacuum rotary evaporator. Extracts were dissolved in 50 $\mathrm{ml}$ chloroform and passed through preconditioned octadecyl (C-18) columns at a rate of 2 $\mathrm{ml} \mathrm{min}{ }^{-1}$ to clean up. The column was washed five times with $5 \mathrm{ml}$ chloroform to recover propoxur residue. Propoxur extracts were evaporated to $5 \mathrm{ml}$ and $1 \mu \mathrm{l}$ aliquot was added for analysis by gas chromatograph.

Each prepared sample was analysed for lindane by gas-liquid chromatographic techniques using Hewlett Packard 5890 series II with integrator (Hewlett Packard 3396A) gas chromatograph equipped with a SPB-608 (length $30 \mathrm{~m}$, ID $0.5 \mathrm{~mm}$ and film thickness of $1.5 \mu \mathrm{m}$ ) fused silica capillary column. The detection system consisted of a ${ }^{63} \mathrm{Ni}$ electron capture detector. The column oven was maintained at $200{ }^{\circ} \mathrm{C}$. The ${ }^{63} \mathrm{Ni}$ detector was operated at $250{ }^{\circ} \mathrm{C}$. The instrument injection ports were at $200{ }^{\circ} \mathrm{C}$. The carrier gas was nitrogen at a flow rate of $25 \mathrm{ml} /$ min. The injection technique was on-column and injection volume was $1 \mu \mathrm{l}$.

Each prepared sample was analysed for propoxur by gas-liquid chromatographic techniques using varian 3700 gas chromatograph equipped with a DB-5 column (length $30 \mathrm{~m}$, ID $0.5 \mathrm{~mm}, 0.25 \mathrm{~m}$ film) and contains polyphenylsilozane. Carrier gas was helium at a flow rate of $30 \mathrm{ml} / \mathrm{min}$. The column oven was maintained at $310{ }^{\circ} \mathrm{C}$, the injected ports at $300{ }^{\circ} \mathrm{C}$ and the flame ionization detector was operated at $320{ }^{\circ} \mathrm{C}$. The injection technique was oncolumn and injection volume was $1 \mu \mathrm{l}$.

\section{RESULTS AND DISCUSSIONS}

The following results were obtained from this study.

Figure 1 indicates that lindane was present in all the parts of the cocoa plant studied. The levels of lindane concentration in cocoa beans ranged from 0.055 to $0.897 \mathrm{mg} / \mathrm{kg}$ with the highest concentration occurring in beans from Abura Dunkwa. However, the Codex Alimentarius Acceptable Daily Intake (ADI) for lindane is $0.001 \mathrm{mg} / \mathrm{kg}$ (FAO/WHO, 1998). The results are comparable to those reported by Lynes (1978) for the West African sub region which ranged between 0.001 and $0.600 \mathrm{mg} / \mathrm{kg}$. The mean concentration of lindane in beans was $0.411 \pm 0.348 \mathrm{mg} / \mathrm{kg}$. The average concentration of lindane in the pod was $1.113 \pm 0.918$ $\mathrm{mg} / \mathrm{kg}$. The concentration ranged from 0.082 to $2.546 \mathrm{mg} / \mathrm{kg}$ with the highest occurring in pod from Twifu Mampong. The concentration range for the testa was from 0.150 to $1.473 \mathrm{mg} / \mathrm{kg}$ with a mean concentration of $0.609 \pm 0.517$ $\mathrm{mg} / \mathrm{kg}$ and the highest concentration occurring in testa was from Abura Dunkwa. Average concentration of lindane in placenta was 0.905 $\pm 0.835 \mathrm{mg} / \mathrm{kg}$. The levels ranged from 0.083 to $2.230 \mathrm{mg} / \mathrm{kg}$ with the highest concentration detected in placenta of samples from Twifu Mampong. An average lindane concentration of $0.892 \pm 0.858 \mathrm{mg} / \mathrm{kg}$ was found for the leaves. However, the concentrations ranged from 0.167 


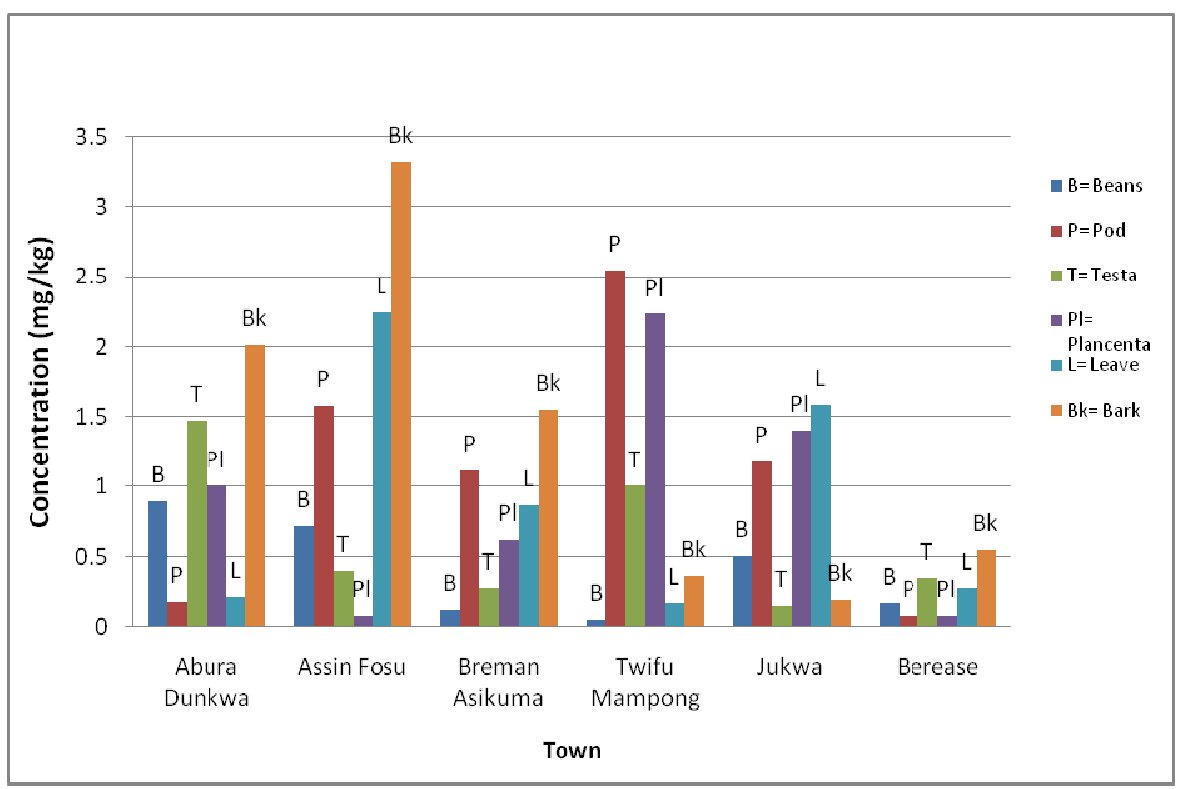

Fig. 1: Lindane residues in cocoa plant in $\mathrm{mg} / \mathrm{kg}$ collected from different districts in Central Region

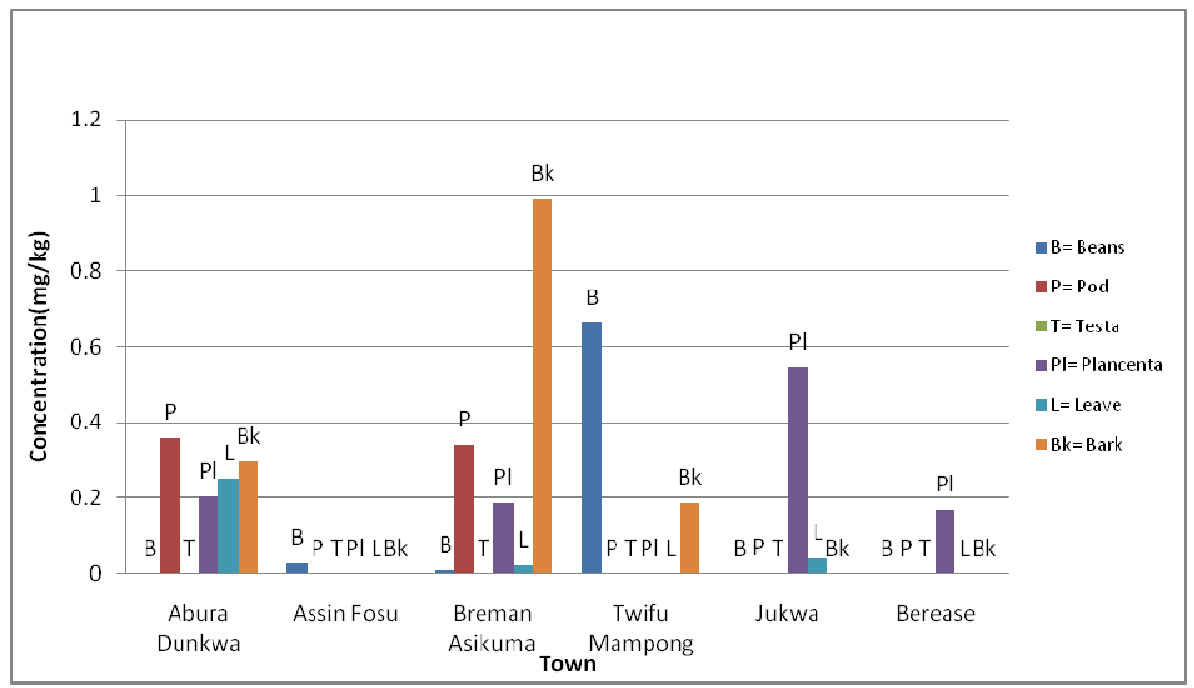

Fig. 2: Propoxur residues in cocoa plant in $\mathrm{mg} / \mathrm{kg}$ collected from different districts in Central Region 
Lindane and Propoxur residues in cocoa...

to $2.245 \mathrm{mg} / \mathrm{kg}$, with the highest detected from leaves from Assin Fosu. The mean concentration of lindane levels in the bark was $1.333 \pm$ $1.208 \mathrm{mg} / \mathrm{kg}$. The bark had concentrations ranging from 0.199 to $3.318 \mathrm{mg} / \mathrm{kg}$. The highest concentration was detected in the bark from Assin Fosu.

The order of lindane concentrations in the various parts of the cocoa tree was

bark $>$ pod $>$ leaves $>$ placenta $>$ testa $>$ beans. The bark is a storage organ in which most unwanted substances are stored. It conducts water, food and chemicals to other parts of the plant. The bark here retains much of the pesticide. The order also suggests that the outer parts are exposed directly to the pesticide during application accumulates much of it. New leaves and fruits are restored year after year to replace old ones. It is therefore not surprising that the bark contains the highest concentration of lindane.

Figure 2 shows that propoxur was not detected in most of the parts of cocoa trees sampled.

The levels of propoxur in the beans ranged between 0.0106 and $0.664 \mathrm{mg} / \mathrm{kg}$, with an average concentration of $0.235 \pm 0.372 \mathrm{mg} / \mathrm{kg}$. The highest concentration of propoxur occurred in beans from Twifu Mampong. The levels, with the exception of those from Twifu Mampong were comparable to the FAO/WHO ADI of $0.02 \mathrm{mg} / \mathrm{kg}$ (Kidd et al., 1991). This suggests that farmers at Twifu Mampong might not be using propoxur properly in agricultural practices. With the exception of Twifu Mampong which had concentration of $0.001 \mathrm{mg} / \mathrm{kg}$ for testa, the rest had levels below detection limit. This can be attributed to the fact that propoxur is not a persistent insecticide. The pod had propoxur levels in the range of 0.003 to $0.361 \mathrm{mg} /$ $\mathrm{kg}$ with the highest level detected in pod from Abura Dunkwa. A mean concentration level of $0.235 \pm 0.335 \mathrm{mg} / \mathrm{kg}$ was found for the pod. A concentration range of 0.169 to $0.544 \mathrm{mg} / \mathrm{kg}$ was detected for the placenta with the highest concentration from Jukwa, and an average of $0.276 \pm 0.179 \mathrm{mg} / \mathrm{kg}$. The levels of propoxur in the leaves from Abura Dunkwa contained the highest concentration. The level falls within 0.021 to $0.252 \mathrm{mg} / \mathrm{kg}$ with an average concentration of $0.104 \pm 0.128 \mathrm{mg} / \mathrm{kg}$. The bark had concentration ranging from 0.189 to $0.991 \mathrm{mg} /$ $\mathrm{kg}$, with a mean concentration of $0.491 \pm 0.436$ $\mathrm{mg} / \mathrm{kg}$. The bark from Breman Asikuma had the highest level. The order of propoxur concentration in the cocoa plant was bark > pod > placenta $>$ leaves $>$ beans $>$ testa. It was observed that the highest concentration of propoxur was detected for the bark of the cocoa and this was the same for lindane.

\section{CONCLUSION}

Comparing the concentrations of the pesticides, it is noted that for the same part, there were higher levels of lindane than propoxur. However, propoxur was sprayed on the cocoa trees during the year of the study. This indicates the higher persistence of lindane in the environment. The fact that propoxur was not detected in many parts of the cocoa plant shows how easily propoxur is decomposed in the environment. From the studies it may be preferable to use propoxur for control of pests in cocoa. The study also revealed that the concentration of lindane in cocoa beans from the Central Region of Ghana was below FAO/WHO recommended maximum residue limit of $1 \mathrm{mg} / \mathrm{kg}$ (Lynes, 1978). The concentration of propoxur in cocoa beans was also comparable to FAO/WHO ADI. This could be attributable to good farming practices. Therefore cocoa beans from Ghana are safe for consumption.

\section{ACKNOWLEDGEMENT}

The authors express gratitude to Messers Osei Akoto, Akwasi Acheampong and Godfred Darko all at KNUST for proof reading the manuscript and making constructive suggestions.

\section{REFERENCES}

Alvarez-Pedrerol, M., Ribas-Fitó, N. and Torrent, M. (2008). "Thyroid disruption at birth due to prenatal exposure to beta -hexachlorocyclohexane". Environ Int . doi: $10.1016 /$ j.envint.2007.12.001. 
P M I D 18207242, http:// linkinghub.elsevier.com/retrieve/pii/ S0160-4120(07)00225-5

Bentum, J. K., Essumang, D. K. and Dodoo, D.K., (2006). Lindane and propoxur residues in the top soils of some cocoa grow ing areas in five districts of the Central Region of Ghana. Bulletin of the Chemical Society of Ethiopia; 20. ( 2) ; 193-199

Commission for Environmental Cooperation. North American Regional Action Plan (NARAP) on lindane and other hexachlorocyclohexane $(\mathrm{HCH})$ isomers. November 30, 2006. http://www.cec.org/ files/PDF/POLLUTANTS/ Lindane NARAP-Nov06_en.pdf

Environment News Service. http:// www.headlice. Org/news/2001/ens-lycos.

FAO/WHO (1998). Codex Alimentarius Commission, Consideration of intake of pesticide Residues: Report on pesticide residue intake studies at international and national level based on revised guidelines for predicting dietary intake of pesticide residues, Reports of $13^{\mathrm{TH}}$ session of the Codex Committee on pesticide residues.

Howard, P. H. (1991). Handbook of Environmental Fate and Exposure Data for Organic Chemicals: Pesticides . Lewis Pub lishers, Chelsea, MI, 3-15

Kidd, H. and James, D. R. (1991). The Agro chemicals Handbook, Third Edition. Royal Society of Chemistry Information Services, Cambridge, UK.

Lynes, J. M.(1978). Anonymous data collected by the Cocoa, Chocolate and Confactionary Alliance, Ministry of Agriculture Fisheries and Food, UK. P 169-173.

Therdteppitak, A. and Yammeng, K. (2003). Determination of organochlorine pesticides in commercial fish by gas chromatography with electron capture detector and confirmation by gas chromatographymass spectrometry. Science Asia, 29:127134.

U.S. Environmental Protection Agency (1988). Health Advisory Summary: (Baygon) Propoxur. Office of Drinking Water, Washington, DC.

U.S. EPA. Evaluation of the Carcinogenic Potential of Lindane, PC. Code: 009001. 2001. http://www.lindane.com/pdf EPA_Cancer_Assessment_of_Lindane200 1. [accessed 26 January 2009].

U.S. FDA Centers for Drug Evaluation and Research. Lindane lotion and lindane shampoo questions and answers. http:// www.fda.gov/cder/drug/infopage/lindane/ lindaneQA.htm Updated April 15, 2003. [accessed 26 January 2009].

UNEP/ILO/WHO (1994). International Programme on Chemical Safety. The WHO recommended classification of pesticides by hazard and guidelines to classification.

WHO (1991). 124-Lindane International programmme on chemical safety. Environmental Health Criteria, 1-15. 